\title{
Winter frequency of western disturbances and precipitation indices over Himachal Pradesh, India: 1977-2007
}

\author{
NARESH KUMAR and B. P. YADAV \\ India Meteorological Department, Lodi Road, New Delhi-110003, India \\ Corresponding author: N. Kumar; e-mail: naresh.nhac@gmail.com \\ SHILPA GAHLOT \\ Indian Institute of Tecnology, Hauz Khas, New Delhi-110 016, India \\ MANMOHAN SINGH \\ Meteorological Centre, Bibra House, Cliffend Estate, Shimla, Himachal Predesh-171001, India
}

Received October 23, 2013; accepted November 3, 2014

\begin{abstract}
RESUMEN
Los Himalayas desempeñan un papel importante en el clima y el tiempo meteorológico de la India, y controlan tanto las perturbaciones del oeste (PO) durante el invierno como el monzón del suroeste durante el verano. En los meses de invierno (diciembre a marzo), los vientos del oeste asociados con PO causan precipitaciones, en ocasiones asociadas a fuertes nevadas y extensas avalanchas sobre Himachal Pradesh. Por tal motivo, el presente estudio analiza la variabilidad temporal de la frecuencia de PO y de diversos índices de precipitación (como número de días húmedos y lluviosos, días con precipitación fuerte y muy fuerte, e intensidad de la precipitación de 1977 a 2007) en Himachal Pradesh durante el invierno. También se analizan las características sinópticas asociadas con PO intensas que provocaron fuertes precipitaciones sobre la región durante el periodo señalado. El análisis de datos revela una tendencia decreciente estadísticamente significativa (con un nivel de confianza $>95 \%$ ) de las PO en la región de estudio. Debido a que la precipitación invernal en Himachal Pradesh ocurre sobre todo como resultado de las PO, tanto la precipitación total como los días con precipitación fuerte y muy fuerte han disminuido en la región. El análisis también muestra una disminución de alrededor de $25 \%$ en los días de precipitación fuerte y de $13 \%$ en la precipitación invernal total sobre Himachal Pradesh respecto de su media respectiva (de 1977 a 2007).
\end{abstract}

\begin{abstract}
The Himalayas have an important role in Indian weather and climate, since they control the western disturbances (WDs) during winter and the southwest monsoon during summer. During the winter months (December to March), westerly winds associated with WDs cause precipitation, sometimes along with heavy snowfall, extensive avalanches, etc., over Himachal Pradesh. Therefore, this study examined the temporal variability in the winter months frequency of WDs and various precipitation indices like wet days, rainy days, rather heavy and heavy precipitation days, and precipitation intensity during 1977 to 2007 over Himachal Pradesh. The study also examined synoptic features associated with intense WDs that caused heavy precipitation over the region during the same period. Analysis of data reveals a statistically significant (confidence level $>95 \%$ ) decreasing trend in the frequency of WDs over this region. Since winter precipitation in Himachal Pradesh mainly occurs due to WDs, total winter precipitation and frequency of rather heavy and heavy precipitation days have decreased over the region. The analysis also shows a decrease of about $25 \%$ in heavy precipitation days and of $13 \%$ in total winter precipitation from their respective mean (from 1977 to 2007) over Himachal Pradesh.
\end{abstract}

Keywords: Himachal Pradesh, precipitation, western disturbances. 


\section{Introduction}

Winter precipitation plays an important role over the Western Himalayan Region (WHR), particularly in Himachal Pradesh, for various sectors like agriculture, water resources, horticulture, hydroelectric power generation and regional economy. Winter precipitation in the WHR occurs under the influence of extratropical systems known as western disturbances (WDs) (Dimri and Dash, 2012; Yadav et al., 2012). These are the extratropical upper air troughs or cyclonic circulations (CCs) in midlatitude westerlies that move west to east across the Himalayan region (Das et al., 2002; Das 2002; Lang and Barros, 2004; Puranik and Karekar, 2009). Under its influence, CCs sometimes develop south of the system at lower levels, in which case they are known as induced CCs. Some WDs produce well-distributed and large amounts of precipitation along with heavy snowfall/rainfall, landslides, cloudbursts etc. over the Himalayan region, while others pass across this area without causing precipitation (Malurkar, 1947). Hence, studies related to WDs and their associated weather are essential to the WHR.

There are many studies related to WDs and their associated weather over the WHR in literature. Pisharoty and Desai (1956) and Rao and Srinivasan (1969) studied the synoptic aspects of WDs and their associated weather over the WHR. They found that about 6-7 WDs per month move across the region. Singh and Kumar (1977) found that WDs intensified over the WHR in association with a pre-existing surface low over central Iran overtaken by a strong upper frontal layer. Rangachary and Bandyopadhyay (1987) and Hatwar et al. (2005) studied the synoptic features associated with extreme weather over the WHR. They found that widespread precipitation along with extensive avalanches over this region occur under the influence of WDs along with a high amount of moisture coming from the Arabian Sea, the Bay of Bengal or both. Das et al. (2002) studied the frequency of WDs in the premonsoon season, as well as its relation with monsoon rainfall and its advancement over northwest India. Their study found a significant decreasing trend in the frequency of WDs during May. Dimri (2005) studied the contrasting features associated with surplus and deficient precipitation years during the winter season to assess the wintertime synoptic weather system affecting the western Himalayas. He found higher heat flux convergence in excess years and higher flux of convergence of kinetic energy with higher dissipation of kinetic energy during surplus years. Dimri (2007) studied the meridional transport of heat, momentum, potential energy and moisture associated with WDs over the Himalayan region due to mean and eddy motion. He observed that significant meridional transport due to mean motion takes place in the upper troposphere at $300 \mathrm{hPa}$ and $200 \mathrm{hPa}$. Raju et al. (2011) studied kinetic energy associated with intense WDs that caused widespread precipitation over northwest India, finding that this phenomenon occurred due to strong flux convergence and adiabatic production of kinetic energy.

There are also studies related to temporal and spatial variability in precipitation over the Himalayan region. Shrestha et al. (2000) studied precipitation across Nepal and found significant variability at annual and decadal time scales. Bhutiyani et al. (2008) have done trend analyses of discharge data from rivers in the northwest Himalayas, finding out that the number of high-magnitude flood events in this region have increased in the last three decades. Bhutiyani et al. (2010) also studied precipitation trends in the northwest Himalayas and did not found any trends in precipitation during the winter season or significant decreasing trends in precipitation during the monsoon season. Kumar and Jain (2010) studied the trends in seasonal annual rainfall and rainy days in the Kashmir Valley using data of five stations within this area. They found decreasing trends in monsoon and winter rainy days over all the stations and a decreasing trend in annual rainfall over three stations. However, there is hardly any study in literature related to frequency of WDs and variability of precipitation indices over the WHR with particular focus on Himachal Pradesh. Therefore, we have studied the frequency of winter WDs and several precipitation indices like total winter precipitation, wet days, rainy days, and rather heavy and heavy precipitation days by using daily precipitation data for the period 1977 to 2007 over Himachal Pradesh. We also examined the synoptic features associated with intense WDs that caused heavy precipitation ( $\geq 64.5 \mathrm{~mm}$ ) events over Himachal Pradesh during the same period.

\section{Data and methodology}

In the present study we used daily precipitation data of 15 rain gauge stations at Himachal Pradesh 
for the period 1977 to 2007 during winter months (December to March). The sources of data are the Bhakra Beas Management Board and the India Meteorological Department. Locations of the rain gauge stations are given in Table I and shown in Figure 1.

Table I. Latitude and longitude of the rain gauge stations.

\begin{tabular}{clcc}
\hline $\begin{array}{c}\text { Station } \\
\text { No. }\end{array}$ & Name & $\begin{array}{c}\text { Latitude } \\
\left({ }^{\circ} \mathrm{N}\right)\end{array}$ & $\begin{array}{c}\text { Longitude } \\
\left({ }^{\circ} \mathrm{E}\right)\end{array}$ \\
\hline 1 & Kalpa & $31^{\circ} 32^{\prime}$ & $78^{\circ} 15^{\prime}$ \\
2 & Shimla & $31^{\circ} 06^{\prime}$ & $77^{\circ} 10^{\prime}$ \\
3 & Manali & $32^{\circ} 16^{\prime}$ & $77^{\circ} 10^{\prime}$ \\
4 & Kasol & $32^{\circ} 00^{\prime}$ & $77^{\circ} 19^{\prime}$ \\
5 & Rampur & $31^{\circ} 26^{\prime}$, & $77^{\circ} 38^{\prime}$ \\
6 & Dharamshala & $32^{\circ} 16^{\prime}$ & $76^{\circ} 23^{\prime}$ \\
7 & Naina Devi Ji & $31^{\circ} 18^{\prime}$, & $76^{\circ} 32^{\prime}$ \\
8 & Bhunter & $31^{\circ} 50^{\prime}$ & $77^{\circ} 10^{\prime}$ \\
9 & Ali & $31^{\circ} 14^{\prime}$, & $76^{\circ} 54^{\prime}$ \\
10 & Kotla & $31^{\circ} 30^{\prime}$ & $77^{\circ} 15^{\prime}$ \\
11 & Sawarghat & $31^{\circ} 14^{\prime}$, & $76^{\circ} 43^{\prime}$ \\
12 & Kahu & $31^{\circ} 13$, & $76^{\circ} 47^{\prime}$ \\
13 & Daslehra & $31^{\circ} 25^{\prime}$ & $76^{\circ} 33^{\circ}$ \\
14 & Suni & $31^{\circ} 14^{\prime}$ & $77^{\circ} 6$ \\
15 & Berthin & $31^{\circ} 25^{\prime}$ & $76^{\circ} 38^{\prime}$ \\
\hline
\end{tabular}

If daily data of a particular month is lower than $80 \%$ in a station, the data of that month is discarded. To study the precipitation indices (Kumar et al., 2012; Brunetti et al., 2000), we divided daily precipitation into the categories shown in Table II.
Table II. Precipitation categories*.

\begin{tabular}{lll}
\hline No. & Event & Precipitation \\
\hline 1 & Wet day & Daily precipitation $\geq 0.1 \mathrm{~mm}$ \\
\hline 3 & Rainy day & Daily precipitation $\geq 2.5 \mathrm{~mm}$ \\
\hline 4 & $\begin{array}{l}\text { Rather heavy } \\
\text { precipitation } \\
\text { day }\end{array}$ & Daily precipitation $\geq 35.6 \mathrm{~mm}$ \\
& $\begin{array}{l}\text { Heavy } \\
\text { precipitation } \\
\text { day }\end{array}$ & Daily precipitation $\geq 64.5 \mathrm{~mm}$ \\
\hline
\end{tabular}

* Precipitation intensity: Average precipitation amount per wet day.

For calculating the frequency of WDs, we considered only those systems that caused precipitation (at least over two stations) over Himachal Pradesh, and we analyzed trough/circulation in midlatitude westerlies associated with WDs from geopotential height $(\mathrm{GPH})$ at mid-tropospheric levels (Zafar and Rasul, 2009) by using NCEP/NCAR reanalysis data (Kalnay et al., 1996).

Finally, trend analysis of WDs and other precipitation indices were carried out by using a linear regression method (Pant and Rupa Kumar, 1997; Krishnakumar et al., 2009) and the Mann Kendall non-parametric test (Kendall, 1976; Kumar and Jain, 2010; Subash et al., 2011). In this study, the trend is said to be statistically significant if the confidence

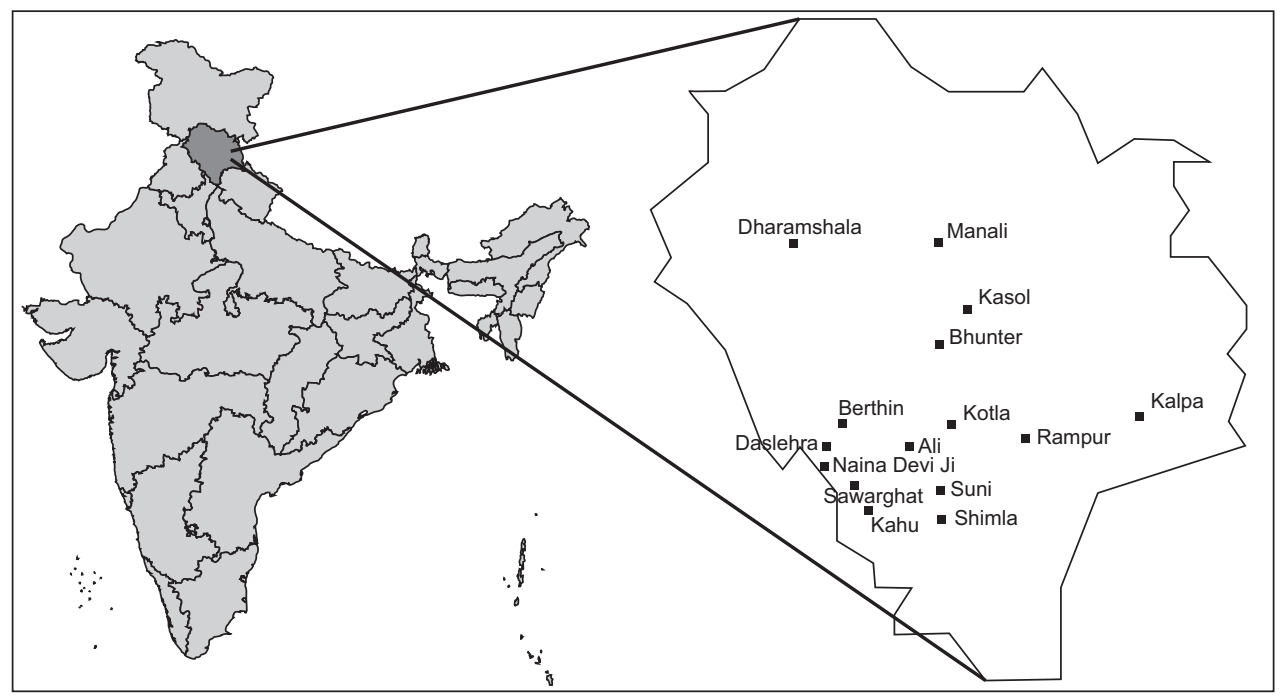

Fig. 1. Location of rain gauge stations in Himachal Pradesh, India. 
level is $\geq 95 \%$. The anomaly percentage of any parameter is calculated as:

$($ series value/series mean $) \times 100$

\section{Results and discussions}

\subsection{Characteristics of intense WDs}

To study the synoptic characteristics of intense WDs, we analyzed about 40 intense WDs that caused heavy precipitation over Himachal Pradesh by using NCEP/ NCAR reanalysis data for the period 1977 to 2007 . In general, the following synoptic features are observed in intense WDs:

a. A trough roughly located along $68^{\circ} \mathrm{E}$ longitude and south of $24^{\circ} \mathrm{N}$ latitude or a CC around $68^{\circ} \mathrm{E}$ longitude and $31^{\circ} \mathrm{N}$ latitude at $500 \mathrm{hPa} \mathrm{GPH}$.

b. An induced CC located over Central Pakistan and the adjoining Rajasthan area or a trough that extends from north Pakistan and the adjoining Jammu and Kashmir to the Arabian Sea at 850 hPa GPH.

c. A large amount of moisture incursion from the Arabian Sea over the region.

A typical example of a trough and induced CC associated with intense WDs that have caused widespread (at more than 75\% stations) precipitation with heavy rainfall in a few places (more than $25 \%$ of stations) is shown in Figure 2. The trough in $500 \mathrm{hPa}$ $\mathrm{GPH}$ is roughly along $67^{\circ} \mathrm{E}$ longitude- $16^{\circ} \mathrm{N}$ latitude along with an induced CC over west Rajasthan and the adjoining Pakistan area at $850 \mathrm{hPa} \mathrm{GPH}$.

\subsection{Winter precipitation indices characteristics}

The average precipitation during winter months for the period 1977 to 2007 over the entire region is of $268 \mathrm{~mm}$. However, this average is $344 \mathrm{~mm}$ over a high altitude region $(>2.0 \mathrm{~km}$ ) (by averaging the precipitation of all stations with altitude greater than $2.0 \mathrm{~km}$ ), $260 \mathrm{~mm}$ over a middle altitude region (between 1.0 and $2.0 \mathrm{~km}$ ) and $225 \mathrm{~mm}$ over a low altitude region $(<1.0 \mathrm{~km})$.

The average frequencies of wet and rainy days over the entire region within the study period are 23 and 17, respectively. The frequencies of rather heavy and heavy precipitation days are 1.5 and 0.3 , respectively, but in a high altitude region the average frequencies of wet days, rainy days, rather heavy precipitation days and heavy precipitation days are 27, 21, 2.1 and 0.3 , respectively. This indicates higher indices of precipitation amount and frequency at higher altitudes, as compared to lower altitudes.

\subsection{Winter disturbances}

The total number of WDs during the study period for winter months is 369 and their annual frequency during the winter season is 12 . Its frequencies during December, January, February and March are of 2, 3, 4, and 4, respectively, whereas earlier studies found that the average frequency of WDs is 6-7 per month across the WHR (Pisharoty and Desai, 1956;
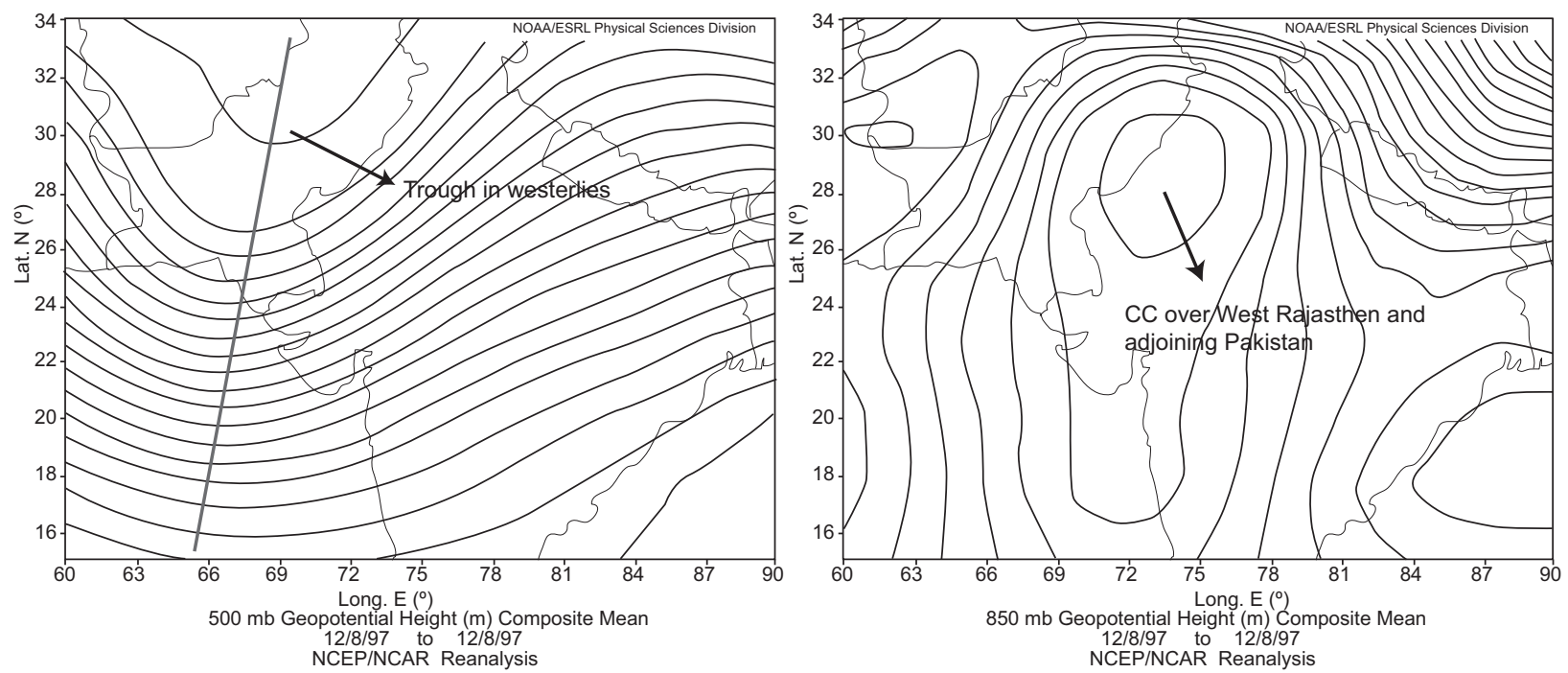

Fig. 2. Locations of troughs and CCs in 500 and $850 \mathrm{hPa}$ GPH, respectively. 
Rao and Srinivasan, 1969). However, our study is based only on central parts of the Himalayas. Further, analysis of data by the linear regression method and the Mann-Kendall non-parametric test indicates a significant decreasing trend in frequency of WDs (Fig. 3) over the region for the period 1977 to 2007. Our study shows a decrease in the frequency of WDs of about $11 \%$ from their mean frequency from 1977 to 2007. Earlier, Das et al. (2002) observed a decreasing frequency of WDs in the pre-monsoon season (March to May) with a significant decrease during May over northwest India. Shekhar et al. (2010) observed no trend in the annual frequency of WDs over higher altitudes in the Western Himalayas.

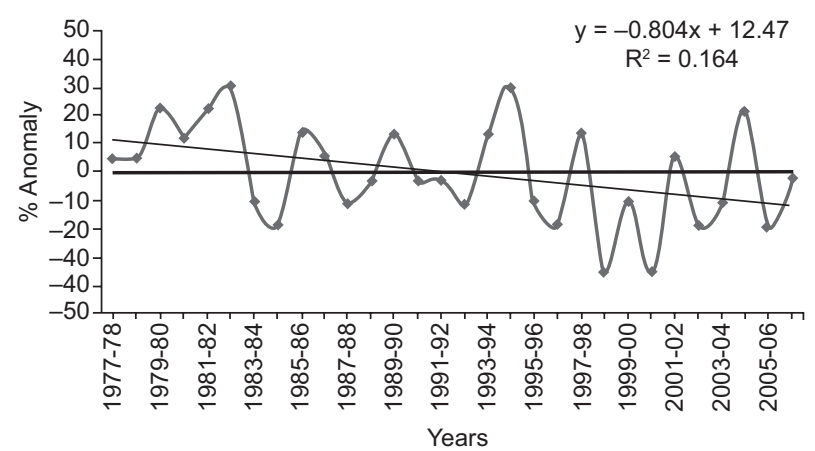

Fig. 3. Winter frequency of western disturbances over Himachal Pradesh.

\subsection{Total winter precipitation}

Total winter precipitation over Himachal Pradesh shows a decreasing trend (Fig. 4) of about 13\% in precipitation from its mean from 1977 to 2007. Earlier studies (Pant et al., 1999; Kumar and Jain, 2010; Shekhar et al., 2010; Dimri and Dash, 2012) also showed decreasing trends in winter precipitation over various parts of the WHR, which may be due to

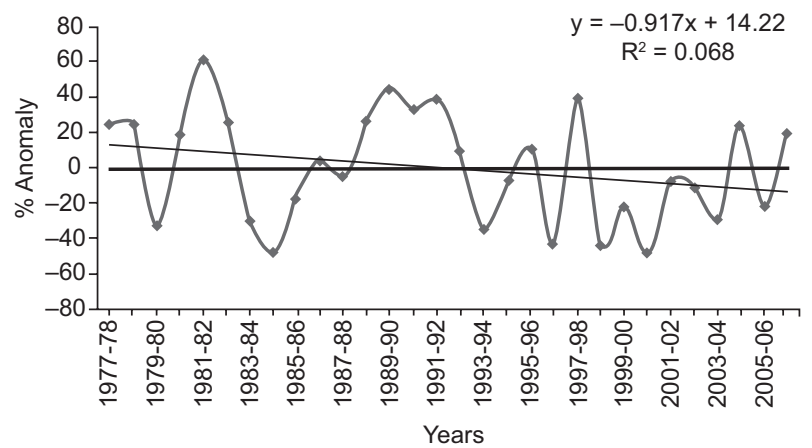

Fig. 4. Winter precipitation trends over Himachal Pradesh. the significant decreasing frequencies of WDs over the region.

\subsection{Wet and rainy days}

Time series of wet and rainy days are shown in Figures 5 and 6, respectively. Our study shows a decreasing trend both in wet and rainy days. A decrease of about $14 \%$ and $13 \%$ was found for wet and rainy days, respectively, from their respective means during the 1977-2007 period. Kumar and Jain (2010) also observed a decreasing trend in winter rainy days over the Kashmir Valley in the Himalayas.

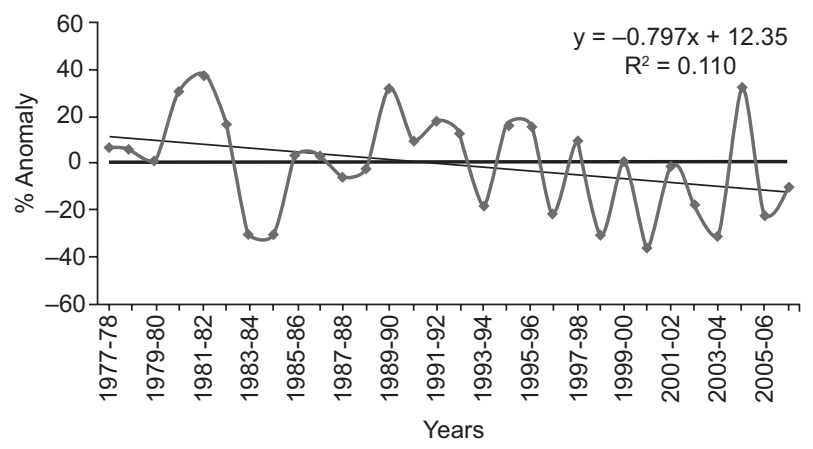

Fig. 5. Wet days trends over Himachal Pradesh.

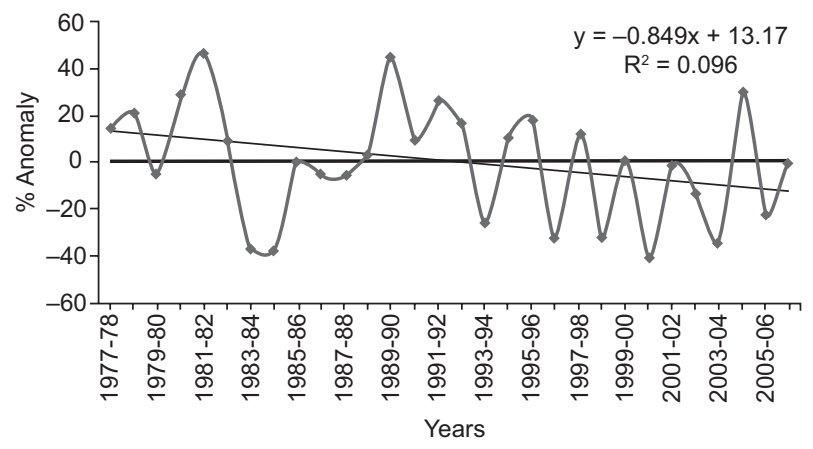

Fig. 6. Rainy days trends over Himachal Pradesh.

\subsection{Precipitation intensity}

The analysis of daily precipitation reveals no change in precipitation intensity over Himachal Pradesh during the study period (Fig. 7).

\subsection{Rather heavy and heavy precipitation}

Time series of rather heavy and heavy precipitation days are shown in Figures 8 and 9, respectively. Both series show decreasing trends over Himachal Pradesh during the study period. The analysis 


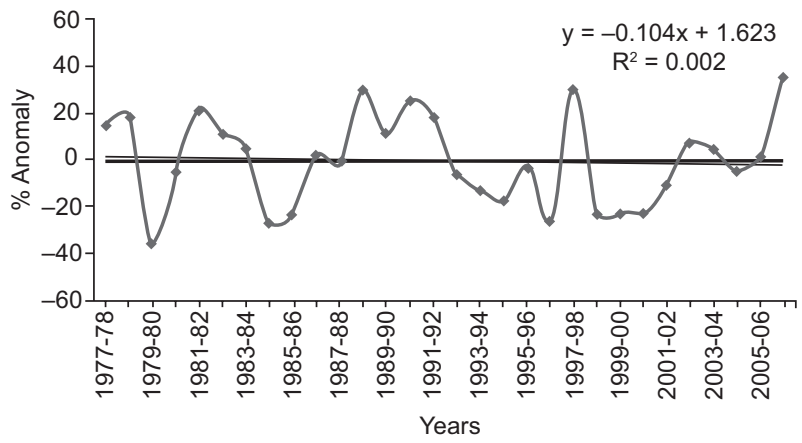

Fig. 7. Trends of precipitation intensity over Himachal Pradesh.

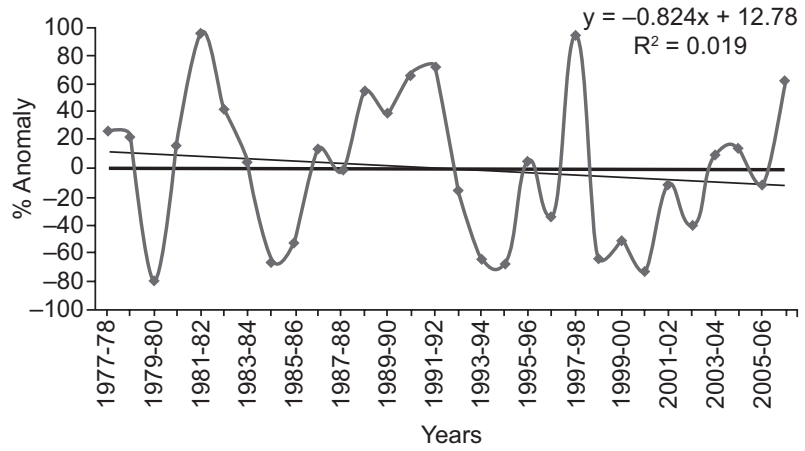

Fig. 8. Rather heavy precipitation trends over Himachal Pradesh.

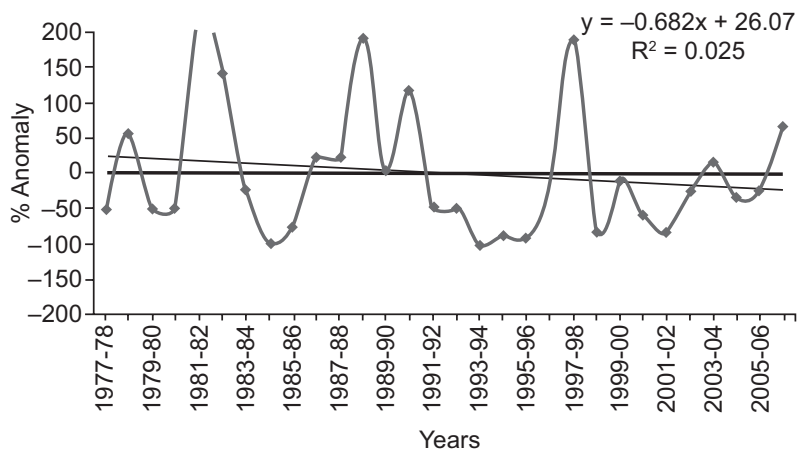

Fig. 9. Heavy precipitation trends over Himachal Pradesh.

indicates a decrease of about $12 \%$ and $25 \%$ in rather heavy and heavy precipitation days from their respective means during the 1977-2007 period. However, long-term changes in heavy precipitation events are not uniform over different parts of the India. Goswami et al. (2006) found significant increasing trends in extreme heavy precipitation over central parts of the country. Kishtawal et al. (2009) observed a significantly increasing trend in the frequency of heavy rainfall over urban regions of India during the monsoon season. Guhathakurta et al. (2011) observed decreasing frequency of heavy rainfall events over major parts of central and north India and increasing frequency in peninsular, east and northeast India. Kumar et al. (2012) observed decreasing trends in heavy precipitation over the Andaman and Nicobar islands.

\section{Conclusions}

Based upon the analysis of daily precipitation data and NCEP/NCAR reanalysis data for the period 1977-2007, the following conclusions are drawn:

Heavy precipitation over Himachal Pradesh generally occurs in association with a trough roughly situated along $68^{\circ} \mathrm{E}$ longitude and south of $24^{\circ} \mathrm{N}$ latitude or a CC located around $31^{\circ} \mathrm{N}$ latitude and $68^{\circ}$ E longitude in mid-tropospheric $(500 \mathrm{hPa})$ westerlies; a CC located over Central Pakistan and the adjoining Rajasthan area, or a trough extended from north $\mathrm{Pa}-$ kistan and the adjoining Jammu and Kashmir to the Arabian Sea in a lower level $(850 \mathrm{hPa})$. In addition, there should be a good amount of moisture incursion from the Arabian Sea over the region.

Total winter precipitation and precipitation indices are greater at higher altitudes as compared to lower altitudes. Tyagi et al. (2013) also observed an increase in winter precipitation with the increase in altitude over the WHR.

The mean frequency of winter WDs that caused precipitation over Himachal Pradesh is 12, with a highest monthly frequency (four) during February and March. This study shows a significant decreasing trend in the frequency of WDs over Himachal Pradesh.

All precipitation indices (i.e., total winter precipitation, wet days, rainy days, rather heavy and heavy precipitation days) show decreasing trends over the region during the study period. However, no trend is observed in precipitation intensity over the region. It can be broadly inferred from the study that the decreasing trend in precipitation indices is mainly due to significant decreases in the frequency of WDs affecting Himachal Pradesh.

\section{References}

Bhutiyani M. R, V. S. Kale and N. J. Pawar, 2008. Changing stream flow patterns in the rivers of northwestern Himalaya: Implications of global warming in the 20th century. Curr. Sci. India 95, 703-708. 
Bhutiyani M. R., V. S. Kale and N. S. Pawar, 2010. Climate change and the precipitation variations in the northwestern Himalaya: 1866-2006. Int. J. Climatol. 30, 535-548.

Brunetti M., L. Buffoni, M. Maugeri and T. Nanni, 2000. Precipitation intensity trends in northern Italy. Int. J. Climatol. 20, 1017-1031.

Das S., 2002. Evaluation and verification of MM5 forecasts over Indian region. 12th PSU/NCAR Mesoscale Model Users Workshop, 24-25 June, Boulder, Co., 77-81.

Das M. R., R. K. Mukhopadhyay, M. M. Dandekar and S. R. Kshirsagar, 2002. Pre-monsoon western disturbances in relation to monsoon rainfall, its advancement over NW India and their trends. Curr. Sci. India 82, 1320-1321.

Dimri A. P., 2005. The contrasting features of winter circulation during surplus and deficient precipitation over Western Himalayas. Pure Apple. Geophys. 162, 2215-2237

Dimri A. P., 2007. The transport of mass, heat and moisture over Western Himalayas during winter season. Theor. Appl. Climatol. 90, 49-63.

Dimri A. P. and S. K. Dash, 2012. Wintertime climate trends in the Western Himalayas. Climatic Change 111, 775-800.

Goswami B. N., V. Venugopal, D. Sengupta, M. S. Madhusoodanan and Prince K. Xavier, 2006. Increasing trend of extreme rain events over India in a warming environment. Science 314, 1442-1445.

Guhathakurta P., O. P. Sreejith and P. A. Menon, 2011. Impact of climate change on extreme rainfall events and flood risk in India. J. Earth Syst. Sci. 120, 359373.

Hatwar H. R., B. P. Yadav and Y. V. Rama Rao, 2005. Prediction of western disturbances and associated weather over Western Himalayas. Curr. Sci. India 88, 913-920.

Kalnay E., M. Kanamitsu, R. Kistler, W. Collins, D. Deaven, L Gandin, M. Iredell, S. Sana, G. White, J. Woollen, Y. Zhu, M. Chelliah, W. Ebisuzaki, W. Higgins, J. Janowiak, K. C. Mo, C. Ropelewski, J. Wang, A. Leetmaa, R. Reynolds, R. Jenne and D. Joseph, 1996. The NCEP/NCAR Reanalysis 40-year Project. Bull. Amer. Meteor. Soc. 77, 437-471.

Kendall M., 1976. Time series. Griffin, London, 197 pp.

Kishtawal C. M., D. Niyogi, M. Tewari, R. A. Pielke Sr. and J. M. Shepherd, 2009. Urbanization signature in the observed heavy rainfall climatology over India. Int. J. Climatol. 30, 1908-1916.
Krishnakumar K. N., G. S. L. H. V. Prasada Rao and C. S. Gopakumar, 2009. Rainfall trends in twentieth century over Kerala, India. Atmos. Environ. 43, 1940-1944.

Kumar V. and S. K. Jain, 2010. Trends in seasonal and annual rainfall and rainy days in Kashmir Valley in the last century. Quatern. Int. 212, 64-69.

Kumar N., B. P. Yadav, A. Tyagi and A. K. Jaswal, 2012. Trend and spatial distribution of rainfall and rainy days over Andaman and Nicobar islands. Nat. Hazards 63, 575-587.

Lang J. T. and A. P. Barros, 2004. Winter storms in the central Himalayas. J. Meteorol. Soc. Jpn. 82, 829-844.

Malurkar S. L., 1947. Abnormally dry and wet western disturbances over north India. Curr. Sci. India 5, 139-140

Pant G. B. and K. Rupa Kumar, 1997. Climates of South Asia. John Wiley and Sons, West Sussex, England, 344 pp. (Belhaven Studies in Climatology).

Pant G. B., K. Rupa Kumar and H. P. Borgaonkar, 1999. Climate and its long-term variability over the western Himalaya during the past two centuries, in: The Himalayan environment (S. K. Dash and L. Bahadur, Eds.). New Age International, New Delhi, 347 pp.

Pisharoty P. R. and B. N. Desai, 1956. Western disturbances and Indian weather. Mausam 7, 333-338.

Puranik D. M. and R. N. Karekar, 2009. Western disturbances seen with AMSU-band infrared sensors. $J$. Earth Syst. Sci. 118, 27-39.

Raju P. V. S., R. Bhatla and U. C. Mohanty, 2011. A study on certain aspects of kinetic energy associated with western disturbances over northwest India. Atmósfera 24, 375-384.

Rangachary N. and B. K. Bandyopadhyay, 1986. An analysis of the synoptic weather pattern associated with extensive avalanching in Western Himalaya. Proceedings of the Davos Symposium on Avalanche Formation, Movement and Effects. IAHS Publication No. 162, pp. 311-316.

Rao. Y. P. and V. Srinivasan, 1969. India Meteorological Department forecasting manual. Part III. Discussion of typical weather situations: Winter western disturbances and their associated features. Deputy Director General of Meteorology, Pune, India, 131 pp.

Shekhar M. S., H. Chand, S. Kumar, K. Srinivasan and A Ganju, 2010. Climate-change studies in the western Himalaya. Ann. Glaciol. 51, 105-112.

Shrestha A. B., C. P. Wake, J. E. Dibb and P. A. Mayewski, 2000. Precipitation fluctuations in the Nepal Himalaya 
and its vicinity and relationship with some large-scale climatological parameters. Int. J. Climatol. 20, 317-327. Singh M. S. and S. Kumar, 1977. Study of a western disturbance. Mausam 28, 233-242.

Subash N., A. K. Sikka and H. S. Ram Mohan, 2011. An investigation into observational characteristics of rainfall and temperature in central Northeast India - a historical perspective 1889-2008. Theor. Appl. Climatol. 103, 305-319.

Tyagi A., N. Kumar and B. P. Yadav, 2012. Climatology of precipitation over western and central Indian
Himalayas. Proceeding of International Symposium on Cryosphere and Climate Change, SASE, Manali, India, pp. 1-9.

Yadav R. K., K. Rupa Kumar and M. Rajeevan, 2012. Characteristic features of winter precipitation and its variability over northwest India. J. Earth Syst. Sci. 121, 611-623.

Zafar Q. and G. Rasul, 2009. Diagnosis and numerical simulation of a heavy rainfall event in winter over upper parts of Pakistan. Pakistan Journal of Meteorology 5, 81-96. 